\title{
Homologous Recombination: A GRAS Yeast Genome Editing Tool
}

\author{
Beatrice Bernardi ${ }^{1,2}$ (1) and Jürgen Wendland ${ }^{2, *} *$ (B) \\ 1 Department of Microbiology and Biochemistry, Hochschule Geisenheim University, Von-Lade-Strasse 1, \\ D-65366 Geisenheim, Germany; Beatrice.Bernardi@hs-gm.de \\ 2 Research Group of Microbiology (MICR)—Functional Yeast Genomics, Vrije Universiteit Brussel, Pleinlaan 2, \\ BE-1050 Brussels, Belgium \\ * Correspondence: juergen.wendland@hs-gm.de; Tel.: +49-6722-502-332
}

Received: 12 May 2020; Accepted: 28 May 2020; Published: 1 June 2020

\begin{abstract}
The fermentation industry is known to be very conservative, relying on traditional yeast management. Yet, in the modern fast-paced world, change comes about in facets such as climate change altering the quality and quantity of harvests, changes due to government regulations e.g., the use of pesticides or $\mathrm{SO}_{2}$, the need to become more sustainable, and of course by changes in consumer preferences. As a silent companion of the fermentation industry, the wine yeast Saccharomyces cerevisiae has followed mankind through millennia, changing from a Kulturfolger, into a domesticated species for the production of bread, beer, and wine and further on into a platform strain for the production of biofuels, enzymes, flavors, or pharmaceuticals. This success story is based on the 'awesome power of yeast genetics'. Central to this is the very efficient homologous recombination (HR) machinery of S. cerevisiae that allows highly-specific genome edits. This microsurgery tool is so reliable that yeast has put a generally recognized as safe (GRAS) label onto itself and entrusted to itself the life-changing decision of mating type-switching. Later, yeast became its own genome editor, interpreted as domestication events, to adapt to harsh fermentation conditions. In biotechnology, yeast HR has been used with tremendous success over the last 40 years. Here we discuss several types of yeast genome edits then focus on HR and its inherent potential for evolving novel wine yeast strains and styles relevant for changing markets.
\end{abstract}

Keywords: homologous recombination; genome editing; wine yeast; lager yeast; fermentation; genetic engineering

\section{The Yeast Saccharomyces cerevisiae-A Companion through the Ages}

Fermented beverages have followed mankind through history and the domestication of barley around 10,000 BC was an indication that alcoholic beverages were an integral part of society [1,2]. In an archaeological investigation of ancient Egyptian pottery dated to approximately 3150 BC during the era of the Scorpion King I, it was found that these vessels were used for beverage fermentations [3]. This indicates that yeast, and particularly the strong fermenting yeast Saccharomyces cerevisiae, was part of human societies first as a Kulturfolger that then became domesticated through continuous use. Domestication events included in the case of a very popular wine yeast, EC1118, the introgression of a high-affinity fructose/ $\mathrm{H}+$ symporter from a closely-related species and horizontal gene transfers of DNA from a wine-spoilage organism, Zygosaccharomyces bailii and another yeast Torulaspora microellipsoides. These alterations provided this wine yeast with genes improving its nitrogen and carbon metabolism and stress responses to harsh fermentation conditions [4-6]. Other introgressions of a region containing SUC2, HPF1, and AWA1 from Saccharomyces paradoxus were specifically found 
in wine yeasts. These genes code for an invertase, a $\alpha$-glucosidase, and a protein involved in haze formation, respectively [7].

Yet, yeasts used an array of genome edits to adapt to wine fermentation conditions. These include loss-of-function mutations, genomic rearrangements by reciprocal translocations, copy number variations, and changes in the level of gene expression. Loss-of-function was observed for the aquaporin genes, $A Q Y 1$ and $A Q Y 2$, which encode channels that promote water transport across the cell membrane. This presents an adaptation to high-osmolarity conditions [8,9]. A chromosomal rearrangement occurred between chromosomes VIII and XVI. By crossing over within the promoter regions of the ECM34 and SSU1 genes an increase in the expression of the SSU1-sulphite exporter was achieved conferring an increased tolerance to high levels of sulphite and shortening the lag phase to the onset of fermentation [10-12]. Another rearrangement between chromosomes XV and XVI had the same effect [13].

Copy number variations and increase in expression were found for CUP1, encoding a copper-binding metallothionein $[14,15]$. These adaptations provide increased tolerance to $\mathrm{CuSO}_{4}$, which has been used as a fungicide against powdery mildew since the 1880s [16]. S. cerevisiae has acquired foreign DNA encoding the oligopeptide transporters FOT1-2 through horizontal gene transfer from Torulaspora microellipsoides, which enhanced wine yeast's ability to transport oligopeptides and provided a fitness advantage in grape must [6].

These natural genome edits allowed the adaptation of wine yeasts to the harsh fermentation conditions with high sugar but low nitrogen availability and the high alcohol levels at the end of fermentation. These routes of domestication events and genome edits in wine yeasts were uncontrolled, but interestingly enough the beneficial mutations selected by vintners and the vast majority of wine strains used today are derived from one cluster suggesting common origin $[17,18]$.

That yeast shaped this human relationship with alcoholic beverages through the millennia was only rather recently discovered by Pasteur in 1863 . The study of microorganisms and the analysis of successful vs. unsuccessful fermentations finally resulted in the generation of pure culture yeast strains. This was first achieved by Emil Christian Hansen working at the Carlsberg Laboratory [19]. He isolated Saccharomyces carlsbergensis, Unterhefe No.1, which was from then on used as a starter culture for beer fermentations. All lager yeasts such as S. carlsbergensis are hybrids of S. cerevisiae and Saccharomyces eubayanus. They belong to two groups, triploid strains of group I, including S. carlsbergensis and $\sim$ tetraploid strains of group II, including S. pastorianus, sharing a common origin [20,21]. Julius Wortmann, working at the Geisenheim Research Institute, inspired by Hansen's work, promoted the isolation and characterization of wine yeasts in the 1890s, some of which are still in use today for wine fermentations [22].

Wine making has changed dramatically in the last one hundred years. Yet, yeast strain improvements did not keep up this pace and were limited to the isolation of interesting strains, particularly of hybrid yeasts [23-27].

The discovery of a sexual cycle in S. cerevisiae was made in the 1930s [28]. Since then yeast genetics has advanced S. cerevisiae to a model eukaryote and the industry's number one workhorse $[29,30]$. The use of fairly unsophisticated genome edits via yeast breeding in advancing lager and wine yeast strains has recently emerged again [31-35]. Commercially, yeast breeding is an interesting technology since it allows the generation of non-GM yeast strains with novel contributions to wine fermentations [36]. The available commercial wine yeast strains are in need of refurbishment, they are "old, but not obsolete-not yet". They are basically derived from the Hansen and Wortmann period, i.e., as ancient as an old mechanical clock from 1890 (Figure 1). However, the application of current knowledge allows for much more precise and straightforward gene and genome edits. Homologous recombination provides one such clean tool for these purposes. 
A

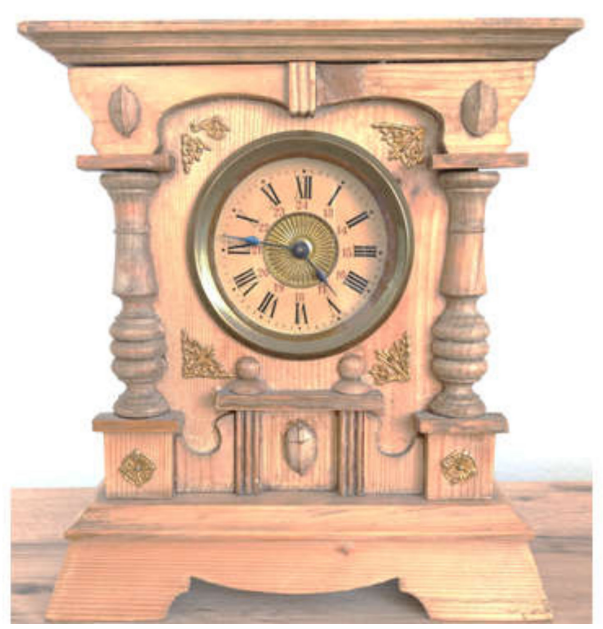

B

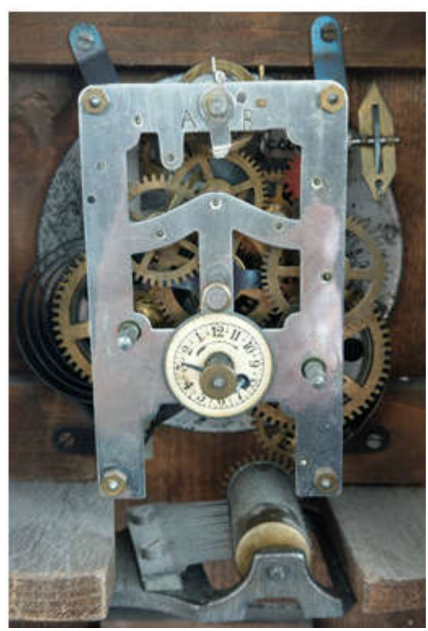

Figure 1. A clock from 1890. (A) Front view and (B) the intricate inner workings of the gears of a mechanical clock combined with a musical clock.

\section{Homologous Recombination-A Trusted ‘Copy + Paste’ Genome Editing Tool}

Prokaryotic and eukaryotic cells have several options to deal with DNA damage [37]. With double-strand breaks (DSBs), two highly conserved, i.e., evolutionarily ancient, systems-HR and non-homologous end-joining (NHEJ) — compete inside a cell to initiate their repair. Their basic features and molecular mechanisms are compared in Figure 2. DSBs can be caused by different exogenous or endogenous stimuli such as ultraviolet or ionizing radiations, genotoxic chemicals, or reactive oxygen species, or caused accidentally during replication [38]. Various facets of DNA repair processes evolved to maintain genome stability [39]. Failure to do so may result in cell death or in cell abnormalities that can lead to cancer $[40,41]$. DNA repair via HR is a highly accurate 'copy + paste' mechanism requiring a template, while NHEJ can stitch together DSBs without a template. This, however, makes NHEJ quite error-prone by placing high priority on repairing a DSB at any cost. The mechanism of choice in DSB repair may be species-dependent, vary with the type of lesion, or be regulated in a cell-cycle-specific manner [42-44].

Although DSBs are deleterious lesions threatening the survival of a cell, some physiological cell processes actually require programmed site-specific DSBs. One example found in S. cerevisiae, is Ho-endonuclease specific DNA cleavage at the MAT locus to initiate mating-type switching (Figure 3) [45]. Deletion of the $H O$ gene, $H O$ for homothallism, generates cells with stable mating type, i.e., heterothallic cells. This indicates that the DSB is required for mating-type switching [46,47]. Heterothallic strains, i.e., ho mutants, are preferred in the laboratory as they can be kept as stable haploid strains [48]. S. cerevisiae wild strains are generally diploid, as mother cells switch mating type and can then form zygotes with their daughter cells. Interestingly, only mother cells can initiate a mating type switch [49]. In daughter cells the $H O$ gene is repressed [50]. To achieve mating type switching yeast cells actually play with fire: they introduce a potentially deadly DSB and trust gene conversion via HR to fix this. By doing so they gain the advantage of being able to form diploid cells that may sporulate and produce Dauerstadien under adverse environmental conditions. The evolution of this mechanism as such is proof that the process is GRAS, generally recognized as safe. 


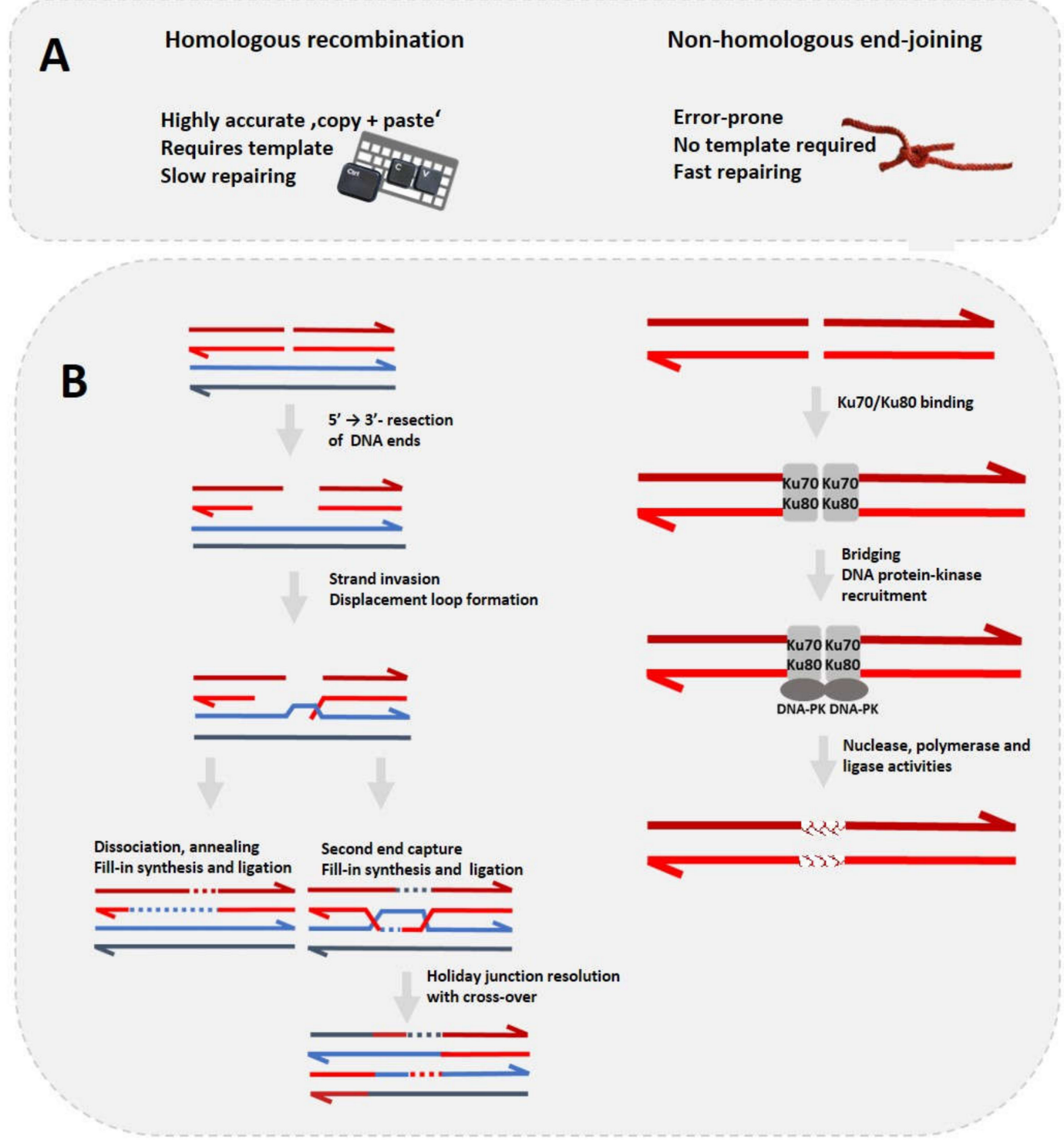

Figure 2. (A) Comparison of homologous recombination (HR) and non-homologous end-joining (NHEJ). On the occasion of a DNA double-strand break there are two possible repair mechanisms. HR (left panel) requires a template, takes several hours to complete but is highly accurate, and is comparable to the "copy + paste" computer command. NHEJ (right panel) does not require a template, is error-prone but faster, and can be associated with rope knotting. (B) Schematic overview of HR (left) and NHEJ (right) mechanisms. HR: after resection of DNA strands by exonuclease, Rad51 and other proteins form a nucleoprotein complex that searches for and invades a template strand to form a D-loop. The displacement loop can be resolved by synthesis-dependent strand annealing (bottom left), which does not result in cross-overs. Double-strand-break repair can resolve the Holiday junctions by either crossover (shown) or non-crossover. NHEJ: the Ku70/Ku80 protein dimer protects DNA ends from degradation/resection and recruits e.g., a DNA-dependent protein kinase catalytic subunit (DNA-PK). Sister chromatids are represented by two arrows, respectively, in red and blue. Light and dark color distinguish DNA strands. Arrows indicate $5^{\prime}-3^{\prime}$ orientations of the DNA strands and dashed lines represent newly- synthetized DNA. 


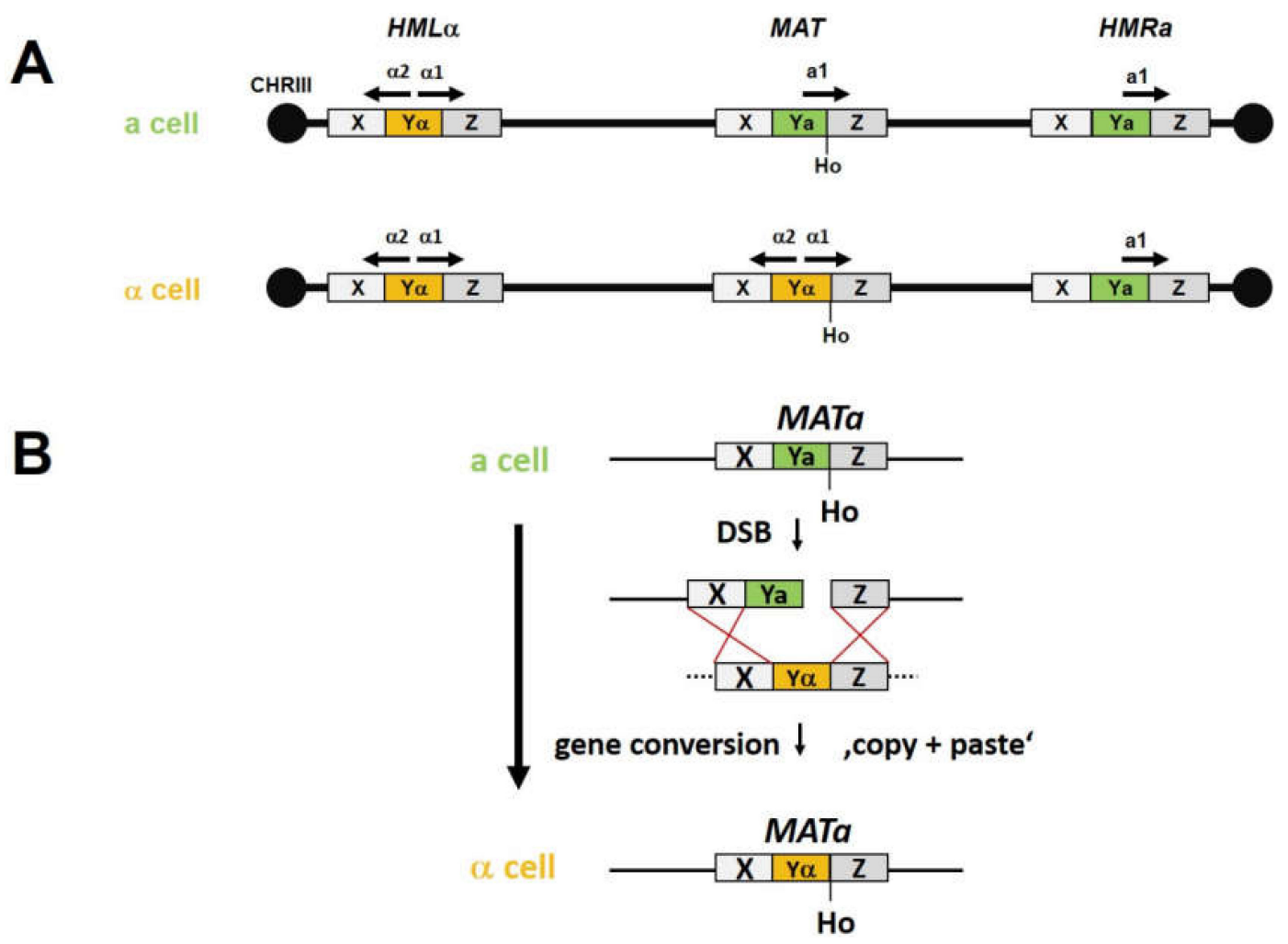

Figure 3. Mating-type switch in Saccharomyces cerevisiae. (A) Cell type in S. cerevisiae is determined by the MAT locus. In a cells there is the a allele at the MAT locus, while $\alpha$ cells possess MAT $\alpha$. The MAT locus resides on CHRIII. At the telomeric ends of this chromosome there are silent cassettes of both mating types, $H M L \alpha$ on the left and HMRa on the right. (B) Mating-type switching is initiated by the Ho endonuclease which cleaves at a specific site at the border of the $\mathrm{Y}-\mathrm{Z}$ region generating a double-strand break (DSB). This triggers a gene conversion using, with high fidelity, the opposite silent mating type cassette as template for DSB repair resulting in a mating-type switch [51].

\section{Progress in Yeast Genome Editing}

Yeast itself is a part-time genome engineer when it re-edits its own genome to achieve a mating-type switch. However, yeast also uses this technology to upgrade itself to be able to survive harsh conditions such as sugar-rich environments of alcoholic beverage fermentations (see above). Once a method of yeast transformation was developed, man stepped in to engineer the yeast genome in various ways. The first genome edit was the gene conversion of a leu2 strain that is auxotrophic for leucine back to leucine prototrophy by providing a LEU2 gene that replaced the defunct allele by gene conversion [52]. This opened new opportunities to study yeast not only on the biochemical level but also on the genetic level. It resulted in several years of intense study of yeast genes. Yet, with the genome sequence of S. cerevisiae established in 1996, it became clear that for the majority of genes no functional studies had been done so far [53].

Mating-type switching uses flanking homology regions of about 700 bp [48]. Yet, remarkably, S. cerevisiae can perform these genome edits with a mere $35 \mathrm{bp}$ of flanking homology region [54]. These short flanking homology regions can be incorporated in oligonucleotide primers so that with a single PCR reaction a disruption cassette can be produced (Figure 4). The efficiency of PCR-based gene targeting combined with a heterologous selectable marker gene, kanMX, was then used to establish the yeast gene deletion collection $[54,55]$. 

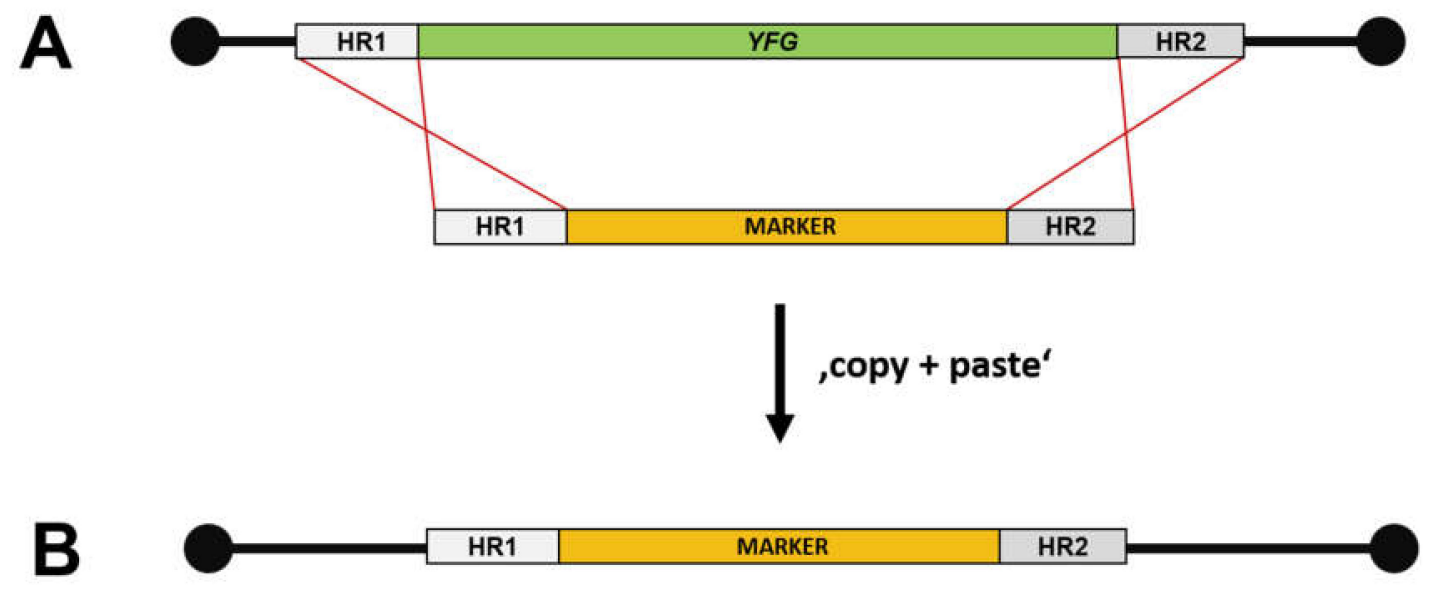

Figure 4. PCR-based gene targeting. (A) A disruption cassette with a selectable marker gene (MARKER) flanked by $5^{\prime}$ - and 3'-homology regions (HR1, HR2) is obtained by PCR amplification and transformed into yeast cells. HR1 and HR2 direct recombination into the target locus of YFG ("your favorite gene").

(B) The marker cassette is now integrated into the locus.

Interestingly, in lager yeast hybrids of S. cerevisiae and S. eubayanus, PCR-based gene targeting could not be employed due to the low efficiency of HR. This seems contradictory but may be due to the polyploidy/aneuploidy of these strains. Overexpression of $R A D 51$, which encodes a key role enzyme of the strand-invasion step or HR (see Figure 2), helped to improve this situation allowing genome edits of these strains [56]. The high in vivo recombination efficiency of S. cerevisiae is also used for in vivo cloning, which is advantageous over cloning via restriction endonucleases and ligation as it works seamlessly without the need to introduce foreign restriction sites to a sequence [57]. Yeast can help building synthetic constructs, e.g., promoter-gene fusions and plasmids and can even assemble complete bacterial genomes from overlapping fragments [58-60]. The limits of this yeast assembly machine have been probed and they are astonishing - in one experiment, 25 large DNA fragments of $17 \mathrm{~kb}$ to $26 \mathrm{~kb}$ in length were used to assemble the genome of Mycoplasma genitalium in S. cerevisiae $[61,62]$. This technology was also used to assemble the completely synthetic $S$. cerevisiae genome (the Yeast 2.0 or Sc2.0 project) [63].

To retrieve transformants with the desired genome edits selectable marker genes are used. This poses two problems-for multiple genome edits several marker genes are required and this is more problematic as these marker genes often code for antibiotic resistance that when left in the genome could contribute to the spread of these genes in the environment. To overcome this problem, marker-recycling methods have been developed. They are based either on non-inducible mitotic recombination between direct repeats or on inducible systems utilizing a recombinase [64]. The URA3 gene is very useful as it serves as a selection marker to trace genome edits, but it can then be selected against using $5^{\prime}$-fluoroorotic acid. In this way mutant strains that have lost the selection marker via recombination or plasmid loss can be identified $[65,66]$. The Cre-loxP method is based on the phage $\mathrm{P} 1$-specific recombination system. loxP is a $34 \mathrm{bp}$ sequence recognized by a recombinase encoded by cre gene [67]. A marker cassette flanked by loxP sites is integrated in the yeast gene locus of interest. Then, the Cre recombinase is expressed in S. cerevisiae (e.g., under the control of the inducible GAL1 promoter on a CEN-ARS plasmid). Recombination between loxP sites leads to the removal of the internal DNA sequence leaving one loxP site behind. Moreover, simultaneous multiple cassettes recombination can be performed [68].

The state-of-the-art technology is seamless genome editing that does not leave behind a genomic imprint at the changed locus. In this way only the desired edits are present in the final strain. A seamless technique that revolutionized the field of genetic engineering, is CRISPR/Cas9 (CRISPR = clustered regularly interspaced short palindromic repeats; Cas = CRISPR associated), which was first applied in S. cerevisiae in 2013 [69]. CRISPR is the basis of a prokaryotic adaptive immunity system protecting 
from incoming phage DNA [70,71]. Cas9 is an endonuclease, which is guided to its target locus by a small RNA. This guide RNA is programmable, i.e., the target sequence can be engineered so that any target in any organism can be manipulated (Figure 5) [72,73]. CRISPR and HR complement one another in generating precise, seamless, and marker-free genome edits.

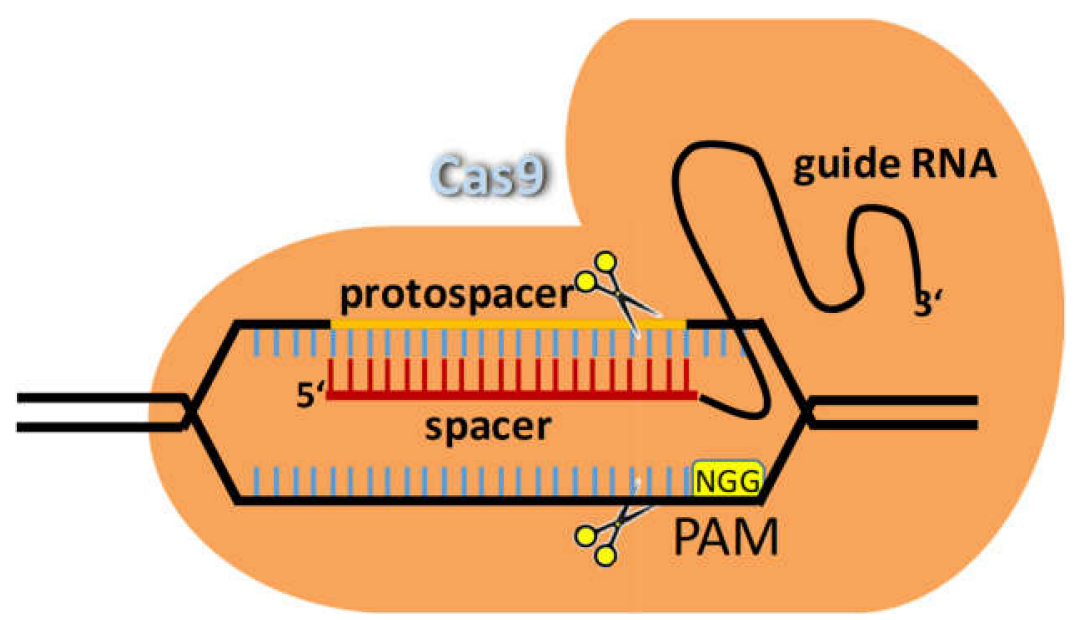

Figure 5. Genome editing via CRISPR/Cas9. Cas9 is a restriction endonuclease (depicted by the scissors) that introduces a DSB at a target sequence defined by the guide RNA. The guide RNA base pairs with the protospacer sequence and Cas 9 cuts if the protospacer adjacent motif (PAM, here NGG required for the Streptococcus pyogenes Cas9) is present.

A profound advantage of CRISPR is the ability to multiplex genome edits. With the ability of Cas9 to interact with different guide RNAs, multiple targets can be attacked in a single cell [74,75]. Multiplexing of genome edits allows complex traits to be mapped, which was used, e.g., to decipher mutations that improve ethanol or glucose tolerance [76]. In this rapidly-developing field other endonucleases have also received attention, in particular Cpf1 (CRISPR from Prevotella and Francisella 1/Cas12a) which is smaller in size than Cas9, lacks a tracrRNA, and utilizes a T-rich PAM is a suitable alternative [77].

\section{Genome Editing in the Beverage Industry}

Key advantages of genome editing over random mutagenesis and selection are the full control over the genome edits and the minimal changes introduced into the genome leaving all other genomic regions unaltered. These key features should be much more appreciated and better communicated into the public domain. Strains to be used in the food and beverage sector need to be approved by regulatory bodies such as the Food and Drug Administration (FDA) in the US, the European Food Safety Authority (EFSA), and the OIV (International Organisation of Vine and Wine). However, beyond facing lengthy regulatory procedures in actually getting approval to use GM strains, there are general consumer distrust and negative opinions towards GM food and beverages. Reasonably, GM yeasts need to compete with regular yeasts in winemaking, and only if they produce a decisive benefit that finds customer approval will any strain and its derived products be successful. Thus, the genome engineers will need to provide this proof to make a convincing and marketable case [78].

There are two generally-different methods of yeast strain design, one that does not introduce foreign DNA and another that uses, e.g., foreign genes to alter metabolic pathways in yeast. The first generates genome edits without introducing any DNA or only introducing genetic material present in the genus Saccharomyces. The idea behind this approach is that these edits could, in principle, also occur naturally by breeding and introgression. This approach is commonly known as 'self-cloning' and acceptable in several countries i.e., these edits are not regarded as generating recombinant organisms [79]. Self-cloned strains include, amongst others: (i) sake and brewer's yeast strains overexpressing the ATF1 gene, which encodes an alcohol acetyltransferase that improves ester formation and flavor production in yeast [80]; 
(ii) the construction of a brewer's yeast strain with the integration of a copper resistance gene (CUP1) into the ILV2 locus, which increases the copper tolerance of this strain, while deletion of one allele of $\alpha$-acetohydroxyacid synthase gene ILV2 results in decreased diacetyl production [81]; (iii) an alternative approach to reduce diacetyl levels used the integration of an extra copy of ILV5, which acts downstream of $I L V 2$, into a bottom fermenting lager yeast strain [82]; and (iv) the overexpression of DUR1,2 or DUR3 in sake and wine yeasts $[83,84]$. Dur1,2 is a urea aminolyase that converts urea into $\mathrm{CO}_{2}$ and $\mathrm{NH}_{3}$. Otherwise, urea may be converted into ethyl carbamate, which is carcinogenic. Dur3 encodes an uptake transporter of urea. A strain overexpressing this gene removes urea from the medium.

This shows that these edits were done on carefully-selected targets that generate beneficial yeast strains not found in nature [85].

The second approach in yeast genome editing also employs genes from other organisms. This is exemplified by the malolactic yeast strain ML01, which has gained FDA approval [86]. This yeast was designed to be able to carry out malolactic fermentation. Malolactic fermentation, i.e., the decarboxylation of malate into lactate, is a secondary fermentation carried out preferably by Oenococcus oeni which follows alcoholic fermentation. This reduces the acidity of many wines. Yet, the use of lactobacilli has several drawbacks, which could be ameliorated by using a wine yeast that takes over this process. To generate ML01 the open reading frames of the O. oeni malolactic gene mleA and the Schizosaccharomyces pombe malate transporter gene mae1 were placed under control of the S. cerevisiae PGK1 promoter and terminator regions and stably integrated into the S. cerevisiae URA3 locus [86]. PGK1 encodes a highly-expressed glycolytic 3-phosphoglycerate kinase. The ML01 strain can now simultaneously perform alcoholic and malolactic fermentations. However, even though this strain has gained approval by the FDA, it was not able to replace bacterial malolactic fermentation in the wine industry.

\section{Genome Edits in Non-GM Yeasts}

Due to customer refusal and legal issues in getting GM yeast approval the industry standard remains on non-GM yeasts. Conventional strain improvement strategies revert to the selection of novel Saccharomyces yeasts and use yeast breeding within S. cerevisiae strains but also between e.g., S. cerevisiae and Saccharomyces kudriavzevii to increase genetic diversity [87]. To introduce change mutagenesis and selection or evolutionary engineering strategies can be employed $[88,89]$. The use of non-conventional and non-fermentative yeasts has been suggested e.g., as flavor enhancers or for the reduction of ethanol content $[90,91]$.

Several selection procedures have been developed over the years to improve yeast strains. To enhance flavor output via channelling amino acids through the Ehrlich pathway is of key importance to improve ester production in yeast [92]. Here the use of toxic fluoro-amino acids has been helpful in selecting yeasts that overproduce the corresponding amino acids by cancelling feedback inhibition. Using tri-fluoroleucine, naturally-occurring mutants of the S. cerevisiae LEU4 gene can be obtained from a culture by simple selection in a non-GM fashion. These mutants show increased leucine biosynthesis, which will result in improved isoamyl acetate flavor production [93,94]. Similarly, mutants resistant to fluorophenlyalanine will be improved in 2-phenylethyl acetate production [95]. To date, these strains have not been commercialized. In addition, no study has been reported to undertake a comprehensive genetic analysis as to which of these mutants is the best flavor producer. To this end mutational analysis of a 70 bp region of the LEU4 gene could be insightful [93].

This demonstrates that workarounds have been developed over the years to improve wine and beer yeasts without genetically modifying them. These efforts are often compared to ploughing a field with many men, horses, and plows instead of using tractors. Grinding these gears has resulted in the characterization and development of several target genes (Figure 6). We still, however, place a billion-euro industry at the hands of technology that dates back to the days of Hansen, Wortmann, and Winge. For nostalgia, the use of the 1890 clock shown in Figure 1 is nice. Yet, this particular clock, 
due to its age and lack of maintenance, lags $10 \mathrm{~min}$ per hour behind real time and is certainly not comparable in accuracy and efficiency to an atomic clock [96].

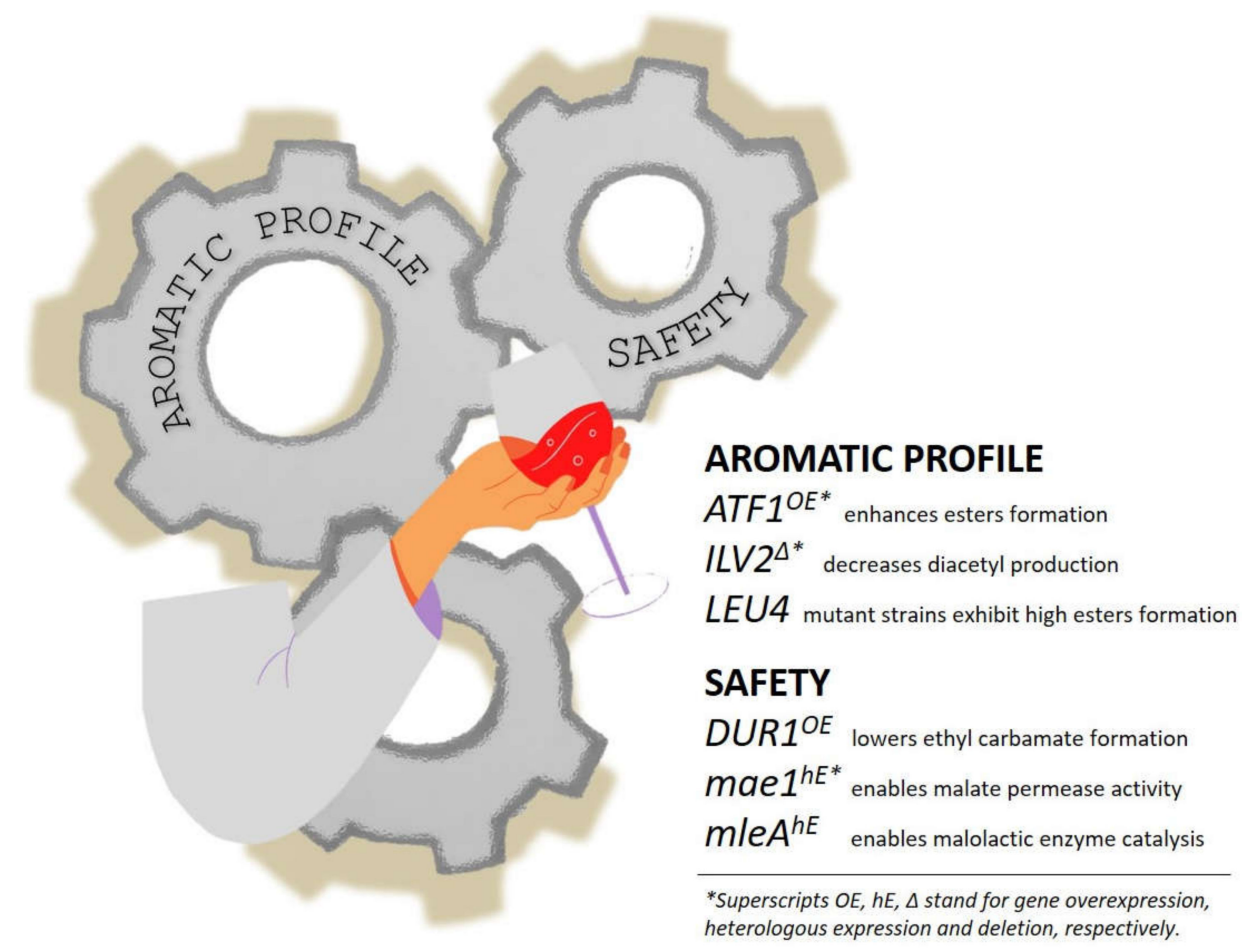

Figure 6. Grind the gears of wine and beer yeasts. The complexity of the aromatic profile can be improved i.e., by disrupting the $\alpha$-acetohydroxyacid synthase gene ILV2 with the decrease of diacetyl production ("butter flavour") or enhancing isoamyl acetate flavor production ("banana flavour") by overexpressing the alcohol-acetyl transferases encoded by ATF1 or mutated LEU4, key-role enzymes in the leucine biosynthesis pathway. The overexpression of urea aminolyase encoded by DUR1,2 decreases the production of urea and therefore of ethylcarbamate (urethane) that has discussed carcinogenic risk. The heterologous expression of $S$. pombe mae1 and O. oeni mleA enables yeast to assimilate malate and convert malic acid into lactic acid, respectively, avoiding the necessity of supplementing bacteria to fermentative batches. For a comprehensive reading about genome edits in wine yeast see [97].

\section{Genome Editing in the 21st Century}

So why do we not employ a trusted technology and embrace the state-of-the-art technology available for yeast genome editing? There are two main issues that are of concern: (i) regulatory requirements on risk assessment including health and safety issues as well as the effect on the environment and (ii) verification of the genome edits.

Since S. cerevisiae is generally recognized as safe, all genome edits in yeast gain the same status. Yet, with each novel strain any impact on safety and potential effects to the environment and its biodiversity need to be assessed. Interestingly, for wine yeasts it was demonstrated that starter culture yeasts were only recovered near the wine cellars of the winery in which they were used and they did not persist and were lost in subsequent years [98]. If one wanted to implement additional strain-specific safety features that decrease the fitness of wine yeasts in natural environments, one could, e.g., remove from these strains the ability to mate and sporulate. The inclusion of signature barcodes could also be used for bio-tracking to trace strains and evaluate their fitness in different environments $[99,100]$.

For the verification of genome edits whole genome sequencing has become the gold standard. This will provide comprehensive data on the intended and any potentially-unintended genome edits and thus secure an unprecedented level of knowledge of each strain. This level of accuracy has already been put to the test in the Sc2.0 synthetic yeast project. The aim of the project is to generate the first functional synthetic eukaryotic genome [63]. During the project complete synthetic chromosomes 
have been assembled in a parental yeast strain. Defects in the fitness of a parent strain bearing one complete synthetic chromosome were rigorously hunted down to ill-designed edits or construction errors which upon their removal resulted in strains of wildtype-like fitness, thus demonstrating the power of modern genome editing and verification tools [101,102].

\section{Conclusions}

The very conservative alcoholic beverage sector certainly does not gain first-mover status for the introduction of state-of-the-art genome editing technology. However, HR combined with next-generation sequencing provides an important advance to the field. We can trust HR in producing yeasts for the beverage sector because we do not have to put all our trust into it; we can verify every single base pair change by genome sequencing. Thus, strains can be designed, generated, and verified to contain exactly those and only those changes that were intended. This provides for maximum safety and reliability, which should convince regulatory authorities such as EU and OIV to install regulations allowing the use of genome-edited yeasts for the benefit of advancing the beer and wine sector.

Author Contributions: Conceptualization, J.W. and B.B; investigation, J.W. and B.B.; writing-original draft preparation, J.W. and B.B.; writing-review and editing, J.W. and B.B.; visualization, B.B. and J.W.; supervision, J.W.; project administration, J.W.; funding acquisition, J.W. All authors have read and agreed to the published version of the manuscript.

Funding: This research was funded in part by the European Union Marie Curie Initial Training Network Aromagenesis 764364 (http://www.aromagenesis.eu).

Acknowledgments: We thank the Aromagenesis network for helpful discussions.

Conflicts of Interest: The authors declare no conflict of interest.

\section{References}

1. Badr, A.; Muller, K.; Schafer-Pregl, R.; El Rabey, H.; Effgen, S.; Ibrahim, H.H.; Pozzi, C.; Rohde, W.; Salamini, F. On the origin and domestication history of barley (Hordeum vulgare). Mol. Biol. Evol. 2000, 17, 499-510. [CrossRef] [PubMed]

2. Dietrich, O.; Heun, M.; Notroff, J.; Schmidt, K.; Zarnkow, M. The role of cult and feasting in the emergence of Neolithic communities. Antiquity 2012, 86, 674-995. [CrossRef]

3. Cavalieri, D.; McGovern, P.E.; Hartl, D.L.; Mortimer, R.; Polsinelli, M. Evidence for S. cerevisiae fermentation in ancient wine. J. Mol. Evol. 2003, 57, S226-S232. [CrossRef] [PubMed]

4. Novo, M.; Bigey, F.; Beyne, E.; Galeote, V.; Gavory, F.; Mallet, S.; Cambon, B.; Legras, J.L.; Wincker, P.; Casaregola, S.; et al. Eukaryote-to-eukaryote gene transfer events revealed by the genome sequence of the wine yeast Saccharomyces cerevisiae EC1118. Proc. Natl. Acad. Sci. USA 2009, 106, 16333-16338. [CrossRef]

5. Galeote, V.; Novo, M.; Salema-Oom, M.; Brion, C.; Valerio, E.; Goncalves, P.; Dequin, S. FSY1, a horizontally transferred gene in the Saccharomyces cerevisiae EC1118 wine yeast strain, encodes a high-affinity fructose $/ \mathrm{H}^{+}$ symporter. Microbiology 2010, 156, 3754-3761. [CrossRef]

6. Marsit, S.; Mena, A.; Bigey, F.; Sauvage, F.X.; Couloux, A.; Guy, J.; Legras, J.L.; Barrio, E.; Dequin, S.; Galeote, V. Evolutionary advantage conferred by an eukaryote-to-eukaryote gene transfer event in wine yeasts. Mol. Biol. Evol. 2015, 32, 1695-1707. [CrossRef]

7. Dunn, B.; Richter, C.; Kvitek, D.J.; Pugh, T.; Sherlock, G. Analysis of the Saccharomyces cerevisiae pan-genome reveals a pool of copy number variants distributed in diverse yeast strains from differing industrial environments. Genome Res. 2012, 22, 908-924. [CrossRef]

8. Will, J.L.; Kim, H.S.; Clarke, J.; Painter, J.C.; Fay, J.C.; Gasch, A.P. Incipient balancing selection through adaptive loss of aquaporins in natural Saccharomyces cerevisiae populations. PLoS Genet. 2010, 6, e1000893. [CrossRef]

9. Goncalves, M.; Pontes, A.; Almeida, P.; Barbosa, R.; Serra, M.; Libkind, D.; Hutzler, M.; Goncalves, P.; Sampaio, J.P. Distinct domestication trajectories in top-fermenting beer yeasts and wine yeasts. Curr. Biol. 2016, 26, 2750-2761. [CrossRef] 
10. Goto-Yamamoto, N.; Kitano, K.; Shiki, K.; Yoshida, Y.; Suzuki, T.; Iwata, T.; Yamane, Y.; Hara, S. SSU1-R, a sulfite resistance gene of wine yeast, is an allele of SSU1 with a different upstream sequence. J. Ferment. Bioeng. 1998, 86, 427-433. [CrossRef]

11. Perez-Ortin, J.E.; Querol, A.; Puig, S.; Barrio, E. Molecular characterization of a chromosomal rearrangement involved in the adaptive evolution of yeast strains. Genome Res. 2002, 12, 1533-1539. [CrossRef] [PubMed]

12. Yuasa, N.; Nakagawa, Y.; Hayakawa, M.; Iimura, Y. Distribution of the sulfite resistance gene ssu1-r and the variation in its promoter region in wine yeasts. J. Biosci. Bioeng. 2004, 98, 394-397. [CrossRef]

13. Zimmer, A.; Durand, C.; Loira, N.; Durrens, P.; Sherman, D.J.; Marullo, P. Qtl dissection of lag phase in wine fermentation reveals a new translocation responsible for Saccharomyces cerevisiae adaptation to sulfite. PLoS ONE 2014, 9, e86298. [CrossRef] [PubMed]

14. Adamo, G.M.; Lotti, M.; Tamas, M.J.; Brocca, S. Amplification of the CUP1 gene is associated with evolution of copper tolerance in Saccharomyces cerevisiae. Microbiology 2012, 158, 2325-2335. [CrossRef] [PubMed]

15. Zhao, Y.; Dominska, M.; Petrova, A.; Bagshaw, H.; Kokoska, R.J.; Petes, T.D. Properties of mitotic and meiotic recombination in the tandemly-repeated CUP1 gene cluster in the yeast Saccharomyces cerevisiae. Genetics 2017, 206, 785-800. [CrossRef] [PubMed]

16. Fay, J.C.; McCullough, H.L.; Sniegowski, P.D.; Eisen, M.B. Population genetic variation in gene expression is associated with phenotypic variation in Saccharomyces cerevisiae. Genome Biol. 2004, 5, R26. [CrossRef]

17. Borneman, A.R.; Forgan, A.H.; Kolouchova, R.; Fraser, J.A.; Schmidt, S.A. Whole genome comparison reveals high levels of inbreeding and strain redundancy across the spectrum of commercial wine strains of Saccharomyces cerevisiae. G3 2016, 6, 957-971. [CrossRef]

18. Eldarov, M.A.; Kishkovskaia, S.A.; Tanaschuk, T.N.; Mardanov, A.V. Genomics and biochemistry of Saccharomyces cerevisiae wine yeast strains. Biochemistry 2016, 81, 1650-1668. [CrossRef]

19. Hansen, E.C. Recherches sur la physiologie et la morphologie des ferments alcooliques V. Methodes pour obtenir des cultures pures de Saccharomyces et de mikroorganismes analogues. C. R. Trav. Lab. Carlsberg 1888, 2, 143-167.

20. Walther, A.; Hesselbart, A.; Wendland, J. Genome sequence of Saccharomyces carlsbergensis, the world's first pure culture lager yeast. G3 Genes Genomes Genet. 2014, 4, 783-793.

21. Wendland, J. Lager yeast comes of age. Eukaryot. Cell 2014, 13, 1256-1265. [CrossRef] [PubMed]

22. Matti, K.; Bernardi, B.; Brezine, S.; Semmler, H.; von Wallbrunn, C.; Rauhut, D.; Wendland, J. Characterization of old wine yeasts kept for decades under a zero-emission maintenance regime. Fermentation 2020, 6, 9. [CrossRef]

23. Gonzalez, S.S.; Barrio, E.; Gafner, J.; Querol, A. Natural hybrids from Saccharomyces cerevisiae, Saccharomyces bayanus and Saccharomyces kudriavzevii in wine fermentations. FEMS Yeast Res. 2006, 6, 1221-1234. [CrossRef] [PubMed]

24. Gonzalez, S.S.; Gallo, L.; Climent, M.A.; Barrio, E.; Querol, A. Enological characterization of natural hybrids from Saccharomyces cerevisiae and S. kudriavzevii. Int. J. Food Microbiol. 2007, 116, 11-18. [CrossRef]

25. Gangl, H.; Batusic, M.; Tscheik, G.; Tiefenbrunner, W.; Hack, C.; Lopandic, K. Exceptional fermentation characteristics of natural hybrids from Saccharomyces cerevisiae and S. kudriavzevii. New Biotechnol. 2009, 25, 244-251. [CrossRef] [PubMed]

26. Perez-Torrado, R.; Barrio, E.; Querol, A. Alternative yeasts for winemaking: Saccharomyces non-cerevisiae and its hybrids. Crit. Rev. Food Sci. Nutr. 2018, 58, 1780-1790. [CrossRef]

27. Langdon, Q.K.; Peris, D.; Baker, E.P.; Opulente, D.A.; Nguyen, H.V.; Bond, U.; Goncalves, P.; Sampaio, J.P.; Libkind, D.; Hittinger, C.T. Fermentation innovation through complex hybridization of wild and domesticated yeasts. Nat. Ecol. Evol. 2019, 3, 1576-1586. [CrossRef]

28. Winge, Ø. On haplophase and diplophase of some Saccharomycetes. C. R. Trav. Lab. Carlsberg 1935, 21, 77-111.

29. Botstein, D.; Fink, G.R. Yeast: An experimental organism for 21st century biology. Genetics 2011, 189, 695-704. [CrossRef]

30. Nielsen, J.; Keasling, J.D. Engineering cellular metabolism. Cell 2016, 164, 1185-1197. [CrossRef]

31. Garcia Sanchez, R.; Solodovnikova, N.; Wendland, J. Breeding of lager yeast with Saccharomyces cerevisiae improves stress resistance and fermentation performance. Yeast 2012, 29, 343-355. [CrossRef] [PubMed] 
32. Bellon, J.R.; Ford, C.M.; Borneman, A.R.; Chambers, P.J. A novel approach to isolating improved industrial interspecific wine yeasts using chromosomal mutations as potential markers for increased fitness. Front. Microbiol. 2018, 9, 1442. [CrossRef] [PubMed]

33. Bellon, J.R.; Yang, F.; Day, M.P.; Inglis, D.L.; Chambers, P.J. Designing and creating Saccharomyces interspecific hybrids for improved, industry relevant, phenotypes. Appl. Microbiol. Biotechnol. 2015, 99, 8597-8609. [CrossRef] [PubMed]

34. Magalhaes, F.; Krogerus, K.; Vidgren, V.; Sandell, M.; Gibson, B. Improved cider fermentation performance and quality with newly generated Saccharomyces cerevisiae $\times$ Saccharomyces eubayanus hybrids. J. Ind. Microbiol. Biotechnol. 2017, 44, 1203-1213. [CrossRef] [PubMed]

35. Origone, A.C.; Rodriguez, M.E.; Oteiza, J.M.; Querol, A.; Lopes, C.A. Saccharomyces cerevisiae $\times$ Saccharomyces uvarum hybrids generated under different conditions share similar winemaking features. Yeast 2018, 35, 157-171. [CrossRef]

36. Krogerus, K.; Magalhaes, F.; Vidgren, V.; Gibson, B. Novel brewing yeast hybrids: Creation and application. Appl. Microbiol. Biotechnol. 2017, 101, 65-78. [CrossRef]

37. Chatterjee, N.; Walker, G.C. Mechanisms of DNA damage, repair, and mutagenesis. Env. Mol. Mutagen. 2017, 58, 235-263. [CrossRef]

38. Zhao, L.; Chang, D.W.; Gong, Y.; Eng, C.; Wu, X. Measurement of DNA damage in peripheral blood by the $\gamma$-H2AX assay as predictor of colorectal cancer risk. DNA Repair 2017, 53, 24-30. [CrossRef]

39. Boiteux, S.; Jinks-Robertson, S. DNA repair mechanisms and the bypass of DNA damage in Saccharomyces cerevisiae. Genetics 2013, 193, 1025-1064. [CrossRef]

40. Finn, K.; Lowndes, N.F.; Grenon, M. Eukaryotic DNA damage checkpoint activation in response to double-strand breaks. Cell Mol. Life Sci. 2012, 69, 1447-1473. [CrossRef]

41. Nogueira, A.; Fernandes, M.; Catarino, R.; Medeiros, R. Rad52 functions in homologous recombination and its importance on genomic integrity maintenance and cancer therapy. Cancers 2019, 11, 1622. [CrossRef] [PubMed]

42. Biehs, R.; Steinlage, M.; Barton, O.; Juhasz, S.; Kunzel, J.; Spies, J.; Shibata, A.; Jeggo, P.A.; Lobrich, M. DNA double-strand break resection occurs during non-homologous end joininging but is distinct from resection during homologous recombination. Mol. Cell 2017, 65, 671-684. [CrossRef] [PubMed]

43. Karanam, K.; Kafri, R.; Loewer, A.; Lahav, G. Quantitative live cell imaging reveals a gradual shift between DNA repair mechanisms and a maximal use of HR in mid S phase. Mol. Cell 2012, 47, 320-329. [CrossRef] [PubMed]

44. Saha, J.; Wang, S.Y.; Davis, A.J. Examining DNA double-strand break repair in a cell cycle-dependent manner. Methods Enzym. 2017, 591, 97-118.

45. Thon, G.; Maki, T.; Haber, J.E.; Iwasaki, H. Mating-type switching by homology-directed recombinational repair: A matter of choice. Curr. Genet. 2019, 65, 351-362. [CrossRef] [PubMed]

46. Jasin, M.; Rothstein, R. Repair of strand breaks by homologous recombination. Cold Spring Harb. Perspect Biol. 2013, 5, a012740. [CrossRef]

47. Haber, J.E. A life investigating pathways that repair broken chromosomes. Annu. Rev. Genet. 2016, 50, 1-28. [CrossRef]

48. Herskowitz, I. Life cycle of the budding yeast Saccharomyces cerevisiae. Microbiol. Rev. 1988, 52, $536-553$. [CrossRef]

49. Sil, A.; Herskowitz, I. Identification of asymmetrically localized determinant, Ash1p, required for lineage-specific transcription of the yeast ho gene. Cell 1996, 84, 711-722. [CrossRef]

50. Long, R.M.; Singer, R.H.; Meng, X.; Gonzalez, I.; Nasmyth, K.; Jansen, R.P. Mating type switching in yeast controlled by asymmetric localization of ASH1 mRNA. Science 1997, 277, 383-387. [CrossRef]

51. Lee, C.S.; Haber, J.E. Mating-type gene switching in Saccharomyces cerevisiae. Microbiol. Spectr. 2015, 3, 491-514.

52. Hinnen, A.; Hicks, J.B.; Fink, G.R. Transformation of yeast. Proc. Natl. Acad. Sci. USA 1978, 75, $1929-1933$. [CrossRef]

53. Goffeau, A.; Barrell, B.G.; Bussey, H.; Davis, R.W.; Dujon, B.; Feldmann, H.; Galibert, F.; Hoheisel, J.D.; Jacq, C.; Johnston, M.; et al. Life with 6000 genes. Science 1996, 274, 547-563. [CrossRef]

54. Wach, A.; Brachat, A.; Pohlmann, R.; Philippsen, P. New heterologous modules for classical or pcr-based gene disruptions in Saccharomyces cerevisiae. Yeast 1994, 10, 1793-1808. [CrossRef] [PubMed] 
55. Giaever, G.; Chu, A.M.; Ni, L.; Connelly, C.; Riles, L.; Veronneau, S.; Dow, S.; Lucau-Danila, A.; Anderson, K.; Andre, B.; et al. Functional profiling of the Saccharomyces cerevisiae genome. Nature 2002, 418, 387-391. [CrossRef] [PubMed]

56. Bernardi, B.; Kayacan, Y.; Akan, M.; Wendland, J. Overexpression of RAD51 enables PCR-based gene targeting in lager yeast. Microorganisms 2019, 7, 192. [CrossRef]

57. Wendland, J. PCR-based methods facilitate targeted gene manipulations and cloning procedures. Curr. Genet. 2003, 44, 115-123. [CrossRef]

58. Gibson, D.G. Synthesis of DNA fragments in yeast by one-step assembly of overlapping oligonucleotides. Nucleic Acids Res. 2009, 37, 6984-6990. [CrossRef]

59. Joska, T.M.; Mashruwala, A.; Boyd, J.M.; Belden, W.J. A universal cloning method based on yeast homologous recombination that is simple, efficient, and versatile. J. Microbiol. Methods 2014, 100, 46-51. [CrossRef]

60. Van Leeuwen, J.; Andrews, B.; Boone, C.; Tan, G. Rapid and efficient plasmid construction by homologous recombination in yeast. Cold Spring Harb. Protoc. 2015, 2015, 085100. [CrossRef]

61. Gibson, D.G.; Benders, G.A.; Axelrod, K.C.; Zaveri, J.; Algire, M.A.; Moodie, M.; Montague, M.G.; Venter, J.C.; Smith, H.O.; Hutchison, C.A., III. One-step assembly in yeast of 25 overlapping DNA fragments to form a complete synthetic Mycoplasma genitalium genome. Proc. Natl. Acad. Sci. USA 2008, 105, 20404-20409. [CrossRef]

62. Juhas, M.; Ajioka, J.W. High molecular weight DNA assembly in vivo for synthetic biology applications. Crit. Rev. Biotechnol. 2017, 37, 277-286. [CrossRef] [PubMed]

63. Pretorius, I.S.; Boeke, J.D. Yeast 2.0-Connecting the dots in the construction of the world's first functional synthetic eukaryotic genome. FEMS Yeast Res. 2018, 18, foy032. [CrossRef] [PubMed]

64. Stovicek, V.; Borja, G.M.; Forster, J.; Borodina, I. Easyclone 2.0: Expanded toolkit of integrative vectors for stable gene expression in industrial Saccharomyces cerevisiae strains. J. Ind. Microbiol. Biotechnol. 2015, 42, 1519-1531. [CrossRef] [PubMed]

65. Boeke, J.D.; Trueheart, J.; Natsoulis, G.; Fink, G.R. 5-fluoroorotic acid as a selective agent in yeast molecular genetics. Methods Enzym. 1987, 154, 164-175.

66. Haase, M.A.B.; Truong, D.M.; Boeke, J.D. Superloser: A plasmid shuffling vector for saccharomyces cerevisiae with exceedingly low background. G3 Genes Genomes Genet. 2019, 9, 2699-2707. [CrossRef]

67. Sauer, B. Recycling selectable markers in yeast. Biotechniques 1994, 16, 1086-1088.

68. Jensen, N.B.; Strucko, T.; Kildegaard, K.R.; David, F.; Maury, J.; Mortensen, U.H.; Forster, J.; Nielsen, J.; Borodina, I. Easyclone: Method for iterative chromosomal integration of multiple genes in Saccharomyces cerevisiae. FEMS Yeast Res. 2014, 14, 238-248. [CrossRef]

69. Di Carlo, J.E.; Norville, J.E.; Mali, P.; Rios, X.; Aach, J.; Church, G.M. Genome engineering in Saccharomyces cerevisiae using CRISPR-Cas systems. Nucleic Acids Res. 2013, 41, 4336-4343. [CrossRef]

70. Horvath, P.; Barrangou, R. CRISPR/Cas, the immune system of bacteria and archaea. Science 2010, 327, 167-170. [CrossRef]

71. Kirchner, M.; Schneider, S. CRISPR-Cas: From the bacterial adaptive immune system to a versatile tool for genome engineering. Angew. Chem. Int. Ed. Engl. 2015, 54, 13508-13514. [CrossRef] [PubMed]

72. Jiang, F.; Doudna, J.A. CRISPR-Cas9 structures and mechanisms. Annu. Rev. Biophys. 2017, 46, 505-529. [CrossRef] [PubMed]

73. Knott, G.J.; Doudna, J.A. CRISPR-Cas guides the future of genetic engineering. Science 2018, 361, 866-869. [CrossRef]

74. Roy, K.R.; Smith, J.D.; Vonesch, S.C.; Lin, G.; Tu, C.S.; Lederer, A.R.; Chu, A.; Suresh, S.; Nguyen, M.; Horecka, J.; et al. Multiplexed precision genome editing with trackable genomic barcodes in yeast. Nat. Biotechnol. 2018, 36, 512-520. [CrossRef] [PubMed]

75. McCarty, N.S.; Graham, A.E.; Studena, L.; Ledesma-Amaro, R. Multiplexed crispr technologies for gene editing and transcriptional regulation. Nat. Commun. 2020, 11, 1281. [CrossRef] [PubMed]

76. Liu, R.; Liang, L.; Choudhury, A.; Garst, A.D.; Eckert, C.A.; Oh, E.J.; Winkler, J.; Gill, R.T. Multiplex navigation of global regulatory networks (minr) in yeast for improved ethanol tolerance and production. Metab. Eng. 2019, 51, 50-58. [CrossRef]

77. Zetsche, B.; Gootenberg, J.S.; Abudayyeh, O.O.; Slaymaker, I.M.; Makarova, K.S.; Essletzbichler, P.; Volz, S.E.; Joung, J.; van der Oost, J.; Regev, A.; et al. Cpf1 is a single RNA-guided endonuclease of a class 2 CRISPR-cas system. Cell 2015, 163, 759-771. [CrossRef] 
78. Pretorius, I.S. Tasting the terroir of wine yeast innovation. FEMS Yeast Res. 2020, 20, foz084. [CrossRef]

79. Kitagaki, H.; Kitamoto, K. Breeding research on sake yeasts in japan: History, recent technological advances, and future perspectives. Annu. Rev. Food Sci. Technol. 2013, 4, 215-235. [CrossRef]

80. Fischer, S.; Buchner, K.R.; Becker, T. Induced expression of the alcohol acetyltransferase gene ATF1 in industrial yeast Saccharomyces pastorianus tum 34/70. Yeast 2018, 35, 531-541. [CrossRef] [PubMed]

81. Wang, D.; Wang, Z.; Liu, N.; He, X.; Zhang, B. Genetic modification of industrial yeast strains to obtain controllable newflo flocculation property and lower diacetyl production. Biotechnol. Lett. 2008, 30, 2013-2018. [CrossRef] [PubMed]

82. Kusunoki, K.; Ogata, T. Construction of self-cloning bottom-fermenting yeast with low vicinal diketone production by the homo-integration of ILV5. Yeast 2012, 29, 435-442. [CrossRef]

83. Coulon, J.; Husnik, J.I.; Inglis, D.L.; van der Merwe, G.K.; Lonvaud, A.; Erasmus, D.J.; van Vuuren, H.J.J. Metabolic engineering of Saccharomyces cerevisiae to minimize the production of ethyl carbamate in wine. Am. J. Enol. Vitic. 2006, 57, 2.

84. Dahabieh, M.S.; Husnik, J.I.; Van Vuuren, H.J. Functional enhancement of sake yeast strains to minimize the production of ethyl carbamate in sake wine. J. Appl. Microbiol. 2010, 109, 963-973. [CrossRef]

85. Schuller, D.; Casal, M. The use of genetically modified Saccharomyces cerevisiae strains in the wine industry. Appl. Microbiol. Biotechnol. 2005, 68, 292-304. [CrossRef] [PubMed]

86. Husnik, J.I.; Volschenk, H.; Bauer, J.; Colavizza, D.; Luo, Z.; van Vuuren, H.J. Metabolic engineering of malolactic wine yeast. Metab. Eng. 2006, 8, 315-323. [CrossRef]

87. Peris, D.; Perez-Torrado, R.; Hittinger, C.T.; Barrio, E.; Querol, A. On the origins and industrial applications of Saccharomyces cerevisiae $\times$ Saccharomyces kudriavzevii hybrids. Yeast 2018, 35, 51-69. [CrossRef]

88. Steensels, J.; Snoek, T.; Meersman, E.; Picca Nicolino, M.; Voordeckers, K.; Verstrepen, K.J. Improving industrial yeast strains: Exploiting natural and artificial diversity. FEMS Microbiol. Rev. 2014, 38, 947-995. [CrossRef]

89. Mans, R.; Daran, J.G.; Pronk, J.T. Under pressure: Evolutionary engineering of yeast strains for improved performance in fuels and chemicals production. Curr. Opin. Biotechnol. 2018, 50, 47-56. [CrossRef]

90. Steensels, J.; Verstrepen, K.J. Taming wild yeast: Potential of conventional and nonconventional yeasts in industrial fermentations. Annu. Rev. Microbiol. 2014, 68, 61-80. [CrossRef] [PubMed]

91. Varela, C.; Sengler, F.; Solomon, M.; Curtin, C. Volatile flavour profile of reduced alcohol wines fermented with the non-conventional yeast species Metschnikowia pulcherrima and Saccharomyces uvarum. Food Chem. 2016, 209, 57-64. [CrossRef] [PubMed]

92. Hazelwood, L.A.; Daran, J.M.; van Maris, A.J.; Pronk, J.T.; Dickinson, J.R. The ehrlich pathway for fusel alcohol production: A century of research on Saccharomyces cerevisiae metabolism. Appl. Env. Microbiol. 2008, 74, 2259-2266. [CrossRef] [PubMed]

93. Cavalieri, D.; Casalone, E.; Bendoni, B.; Fia, G.; Polsinelli, M.; Barberio, C. Trifluoroleucine resistance and regulation of $\alpha$-isopropyl malate synthase in Saccharomyces cerevisiae. Mol. Gen. Genet. 1999, 261, 152-160. [CrossRef]

94. Abe, T.; Toyokawa, Y.; Sugimoto, Y.; Azuma, H.; Tsukahara, K.; Nasuno, R.; Watanabe, D.; Tsukahara, M.; Takagi, H. Characterization of a new Saccharomyces cerevisiae isolated from hibiscus flower and its mutant with L-leucine accumulation for awamori brewing. Front. Genet. 2019, 10, 490. [CrossRef]

95. Cordente, A.G.; Solomon, M.; Schulkin, A.; Leigh Francis, I.; Barker, A.; Borneman, A.R.; Curtin, C.D. Novel wine yeast with $A R O 4$ and TYR1 mutations that overproduce 'floral' aroma compounds 2-phenylethanol and 2-phenylethyl acetate. Appl. Microbiol. Biotechnol. 2018, 102, 5977-5988. [CrossRef]

96. Bloom, B.J.; Nicholson, T.L.; Williams, J.R.; Campbell, S.L.; Bishof, M.; Zhang, X.; Zhang, W.; Bromley, S.L.; Ye, J. An optical lattice clock with accuracy and stability at the $10^{-18}$ level. Nature 2014, 506, 71-75. [CrossRef]

97. Van Wyk, N.; Grossmann, M.; Wendland, J.; von Wallbrunn, C.; Pretorius, I.S. The whiff of wine yeast innovation: Strategies for enhancing aroma production by yeast during wine fermentation. J. Agric. Food Chem. 2019, 67, 13496-13505. [CrossRef]

98. Valero, E.; Schuller, D.; Cambon, B.; Casal, M.; Dequin, S. Dissemination and survival of commercial wine yeast in the vineyard: A large-scale, three-years study. FEMS Yeast Res. 2005, 5, 959-969. [CrossRef]

99. Jackson, C.A.; Castro, D.M.; Saldi, G.A.; Bonneau, R.; Gresham, D. Gene regulatory network reconstruction using single-cell RNA sequencing of barcoded genotypes in diverse environments. Elife 2020, 9, e51254. [CrossRef] 
100. Schmidt, S.A.; Kolouchova, R.; Forgan, A.H.; Borneman, A.R. Evaluation of saccharomyces cerevisiae wine yeast competitive fitness in enologically relevant environments by barcode sequencing. G3 Genes Genomes Genet. 2020, 10, 591-603. [CrossRef]

101. Mitchell, L.A.; Wang, A.; Stracquadanio, G.; Kuang, Z.; Wang, X.; Yang, K.; Richardson, S.; Martin, J.A.; Zhao, Y.; Walker, R.; et al. Synthesis, debugging, and effects of synthetic chromosome consolidation: SynVI and beyond. Science 2017, 355, eaaf4831. [CrossRef] [PubMed]

102. Wu, Y.; Li, B.Z.; Zhao, M.; Mitchell, L.A.; Xie, Z.X.; Lin, Q.H.; Wang, X.; Xiao, W.H.; Wang, Y.; Zhou, X.; et al. Bug mapping and fitness testing of chemically synthesized chromosome X. Science 2017, 355, eaaf4706. [CrossRef] [PubMed]

(C) 2020 by the authors. Licensee MDPI, Basel, Switzerland. This article is an open access article distributed under the terms and conditions of the Creative Commons Attribution (CC BY) license (http://creativecommons.org/licenses/by/4.0/). 